\title{
The Atlantic Tsunami on November 1st, 1755: World Range and Amplitude According to Primary Documentary Sources
}

\author{
Paul-Louis Blanc \\ Institut de Radioprotection et de Sûreté Nucléaire, \\ Fontenay aux roses, \\ France
}

\section{Introduction}

On Saturday, November 1st, 1755, at about 9:40, Lisbon underwent the strongest tsunamigenic earthquake ever reported by witnesses in Western Europe. Many people, attending the religious offices of All Hallows, were killed by the collapse of churches. Some took refuge on the quays of the Tagus, attempting to escape the fall of debris from collapsing buildings and to flee on boats: but a tsunami, 5 to $10 \mathrm{~m}$ high according to various accounts, struck downtown Lisbon. Fire outbreaks, lit by houses collapsing on their kitchen fire, set the town to flames, which raged for almost one week.

The event triggered a competition between Scientific Institutions and between Gazettes to provide their members or readers with original accounts: a reaction similar to what we witnessed on the WEB after the December 26th, 2004 earthquake in Sumatra. In that case, thanks to the speed at which the information now travels, and constraint provided by photography and video-movies, the result has been the gathering of a rich array of accurate observations and data. At variance, in 1755-56, under the escalation of the competition between institutions or journals, with a small number of qualified observers and slow travel of letters conveying the accounts, the exaggerations of compilers were let loose. The reliability of the testimonies suffered in the process: many are contradictory, both in terms of lack of internal consistency and of contradiction between reports.

The Andaman-Sumatra earthquake and tsunami have awoken a public awareness of the risk of tsunami. The November 1st, 1755 tsunami caused by the Great Lisbon Earthquake, remains the only destructive event of the kind on the European Atlantic shores to have been described in some detail in the past, partly supplemented by the tsunami of March 31st, 1761. The primary accounts of the 1755 event are in no danger to loose their documentary importance : the simulations now attempted to evaluate the tsunami risk to human lives and coastal settlements must be constrained by "real data, deducted from historical reports" (Mendes-Victor et al., 2005). But the data gathered from such reports are so dispersed that they cannot be applied without a critical analysis.

In the Ibero-Moroccan gulf, the recent study of a restricted selection of primary documents made it possible to unravel some relationships between classical reports on the tsunami in Cadiz, and to show that it was not as high as the classical estimates had made it: the conclusion was to accept a tsunami wave at shoreline $2.5 \mathrm{~m}$ high above the expected 
astronomical tide and to disregard a previously accepted height of $19.5 \mathrm{~m}$, already downgraded to $18.3 \mathrm{~m}$ with the abandonment of the old French "Pied de Roy" units.

A review of early Europeans documents reporting on the same event in Morocco led to similar conclusions, but the analysis was made more difficult : [1] by the confusion between the effects of the November $1^{\text {st }}$ earthquake and tsunami and those of the November $18^{\text {th }}-19^{\text {th }}$ Rifian earthquake (purportedly also dated November 29th by Arabic sources) ; [2] by the general loose knowledge, in Europe, at the time, of Moroccan geography and toponymy ; [3] by the scarcity of European observers and the ill-qualification of some of them for the task. The idea that in Tangier the tsunami wave reached 14 to $16 \mathrm{~m}$ at shoreline must be abandoned, as well as the notion of a $24.5 \mathrm{~m}$ wave in the Portuguese stronghold of Mazagão in El Jadida. This article extends these results to the whole Atlantic basin, by reviewing the extent, amplitude or other available parameters of the November 1st, 1755, tsunami, considering the earliest accounts (Primary Documentary Sources) recorded in European archives and journals. This implies that later documents (1757 to present) can only be of use if we trust that the actual writing was contemporaneous, or as far as they quote older documents, if the original character of the cited document resists critical analysis.

\section{British Isles}

\subsection{Ireland}

\subsubsection{Cork}

Two letters to the Royal Society of London (Nicola, 1756 ; Hen. Tom. 1756) and a dispatch in the Gentleman's Magazine (Gent's Mag., 1756b) mention that the shock of earthquake was felt in Cork. The Royal Society letters then undermine the reliability of the information: Hen. Tom. allocates it the same time as the tsunami in Kinsale: but seismic waves travel much faster in the mantle and crust than tsunami waves on the ocean, they should only be simultaneous at the epicentre, which was definitely not South-East Ireland; Nicola declares: "I have not met any persons of credit who pretend to say they felt it" ; but a lack of so-called creditable witness is no proof that it did not happen.

The second part of the dispatch in the Gentleman's Magazine carries valuable details. The time of the event, 9:30 AM, may be correct within an error margin of some minutes, as Cork is under a more easterly longitude than Lisbon. Limits are assigned to the places affected in town and the surroundings:

"the limits of the places affected were, southward, Watergate-lane, Christ-church-lane and Playhouse-street; Northward, Broad-lane, Coal-kay and Draw-bridge. I do not find that it was felt more easterly than alderman Bradshaw's, not more westerly than Hammond's Marsh. The limits were so narrow, I / / think that the great torrent of waters that ran down the river Lee has found a passage through the middle part of our city."

This cannot be a description of an earthquake in the common acceptance of the word, they do not show sharp limits to the zones affected. The place-name mentioned are related to low areas and water: Water-gate lane, Coal-kay, Draw-bridge and Hammond's Marsh speak by themselves. Christ-church was not far from the ancient Water-gate. These limits are described as narrow: they follow the banks of the river Lee. The account ends up with a torrent of water running down the river Lee, finding a passage through the middle part of the town.

The explanation reconciling these elements, plus the doubts of Nicola, is that the earthquake itself was not felt, but the bay of Cork, a wide ria reinvaded by marine waters in post-glacial times, was travelled up by a bore. Cork being at the narrow end of the ria, the bore invaded 
part of the town, flooding the river quays and a few streets, and a swampy area beyond town, between the main arms of the river. This bore, almost simultaneous to the quake itself, was caused by the seismic low-frequency surface ground-waves. If a torrent of water ran down the river Lee, it means that a bore had first to run it up.

No ground movement was felt in Cork, but the almost simultaneous consequence was: the water effects of the event were reported all over northern Europe at the time, as far as Norway and Finland. It is just a matter of definition: the Hydrosphere is an integral part to the Earth, but it is unusual to consider water movements as earth movements, let alone quakes.

This interpretation is reinforced by the description given six years later by the London Chronicle, and re-circulated to the Royal Society by Borlase, of the earthquake of March 31st, 1761, again in Cork:

"Extract of a letter from Cork, March 31. A quarter after twelve this day a shock of an earthquake was felt here in the Exchange, in the Merchants Coffee-house, and from the beginning of the Red-House Walk to the East Marsh, between the gates only, just as it was in November 1755 ; but allowed to have been more violent by all that felt it. It did not continue above one minute, undulating from East to West, and vice versa." (Lond. Chron., $1761 \mathrm{~A}$ ).

An East to West undulation, reflected at the end of its course, can only describe the propagation of a wave at the surface of a liquid medium. Again, the time difference with Kinsale, only reached by the tsunami six hours later on the same day, is decisive (Lond. Chron., 1761 B).

\subsubsection{Kinsale}

Several papers and useful comments report the tsunami in Kinsale, in the Gentleman's Magazine (Gent's Mag., 1756b), and in the Philosophical Transactions of the Royal Society (Hen. Tom., 1756; Nicola, 1756; Huxham, 1756; Borlase, 1756). These are indeed observations of the tsunami: the time is tolerably acknowledged: between 2 and 3 PM for Nicola; "not till 3 or 4 afternoon" for Huxham; Borlase adds "not a full hour after us, but above two hours sooner than at Swansea", making sense because his observations in Cornwall were made little after 2 PM. We can accept 3 PM as the arrival time in south-east Ireland, 5 1/2 hours later than the surge in Cork.

Kinsale is also an estuary harbour, re-invaded by marine waters during the last glacial retreat, and as such penetrating far inland. The progressively diminishing depth and decreasing width explain that the run-up remained high. Nicola attributes to one $\operatorname{Rev}^{\mathrm{d}} \mathrm{Mr}$ Keef, a $1.68 \mathrm{~m}$ measurement for the final run up at the Market quay, against an estimate of 1.83 to $2.13 \mathrm{~m}$ by the Gentleman's Magazine. Nicola states that the Market-quay was overflowed, and workers "ran off, but could not do it with expedition enough to prevent their being overtaken, and up to the knees." This is contradictory with the purported height of 1.7 to $2.1 \mathrm{~m}$, which has to be discarded as exaggeration: only the Gentleman's Magazine reports that some ships were not only tossed to and fro, but also lifted and left aground: According to Hen. Tom, they were just left on shore, not quite grounded, and the Marketquay, the dead end of the cul-de-sac of the ria, was inundated: but only to a level of $0.5 \mathrm{~m}$.

Despite havoc among the ships, the event remained rather mild for a tsunami, but its nature is also demonstrated by its periodic character: The period is given as "seldom more than a quarter of an hour between each return" by the Gentleman's Magazine. and the oscillations

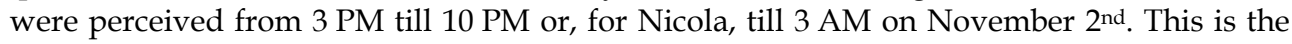
northernmost record which we know of: if it reached further than Kinsale, there is no record. 


\subsection{Wales: Swansea}

The northernmost indication of this tsunami on the main island is in Swansea (S-W coast of Wales). There are two references, in the Philosophical Transactions (Philos. Trans., 1756a), and in the Gentleman's Magazine (Gent's Mag., 1756b) also published early in 1756. A third one, the earliest to mention the tsunami there, cannot be considered a true primary document: it was written in Cornwall and only discusses the time of occurrence (Borlase, 1756). All three concur on the time of the event, 6:45 PM. A single bore "rushed up with a great noise, floated two large vessels, the least above two hundred tons (one whereof was almost dry before), broke their moorings, and hove them, across the river, and had like to overset them, by throwing them on the banks. The whole did not last ten minutes; the rise and fall; and // it was not felt in any other part of the river". A ferry on the same estuary was unaffected. The location where this was observed is clear: the ruins of the White Rock Copper Works, first established 1736, were designated an industrial archaeology park during the 1980 's. The river there is subject to tides. Neither amplitude estimate, nor indication of multiple waves, are given : but the late time of the observation, nine hours later than the earthquake, shows that it was the true tsunami, not a seiche caused by the transmission of low frequency surface waves in the solid crust.

\subsection{Cornwall}

\subsubsection{St-Ives \& Hayle}

Borlase (1756) engaged in investigations extending not only to the St-Michael' Mount's Bay, but also to the harbours of St-Ives and Hayle, facing St George's Channel and the Irish Sea, 5 $\mathrm{km}$ to the North. He did not witness the facts which he records, but his position as the Church of England Pastor for Ludgwan and St Just allowed him to meet people of various condition and gather a wide array of data. The maximum crest to trough amplitude is surprisingly high, from 2.44 to $2.74 \mathrm{~m}$ at St-Ives, but it is also observed that the wave did not break: it had lost impetus. The reason given by Borlase, that the swell had to skirt a circuit of land around Land's End, from Mount's Bay to St-Ives and Hayle, is questionable: the Irish sea is a direction quite as open to a wave coming from the south as the entrance of the Channel. The wave was even weaker in Hayle, secluded from the open sea by the Porth Kidney sands, where Borlase ascribes a $2.13 \mathrm{~m}$ crest to trough amplitude to the highest oscillation, the others being given for only $0.61 \mathrm{~m}$ : but the wording "rose and fell but two feet only" might well mean the simple, positive amplitude: rising two feet plus felling two feet would do for a $1.22 \mathrm{~m}$ crest to trough wave train. The waves only sent vagrant a few ships or boats: "... at St Ive's, a few miles distant, a vessel that was near dry, floated off some distance from the place." (Gent's Mag., 1756b).

\subsubsection{Mount's-Bay: St-Michael's Mount, Penzance, Newlyn, Mousehole}

The observations of the Revd William Borlase (Borlase, 1756) are among the most detailed and the less anecdotal, as he recorded the time, the amplitude and the direction of the water movements, rather than the feelings, impressions and frights of the witnesses.

The phenomenon occurred "a little after two o'clock in the afternoon, // about half an hour after ebb" in the sense of high tide. At the Mount, the apparent flow was "from the eastward // running to the west, and south-west". At the Mount's pier, the measurement of the crest to-trough amplitude was $1.83 \mathrm{~m}$ :

"It continued to swell and rise for the space of ten minutes; it then began to retire for about ten minutes, till the water was six feet lower than when it began to retire. The sea then 
began to return, and in ten minutes it was at the before-mentioned extraordinary height; in ten minutes more it was sunk as before, and so it continued alternately to rise and fall between five and six feet, in the same space of time."

Borlase thus also indicates that the period was $20 \mathrm{~min}$. The maximum amplitude of the wave was reached during the third and fourth periods, and the tsunami was perceived for almost six hours.

In Penzance, the amplitude was stronger: $2.44 \mathrm{~m}$ and a direction seeming from South-East, stronger again in Newlyn, where it broke into a bore more than $3.05 \mathrm{~m}$ high, travelling in a northerly direction. In Mousehole the wave is only mentioned. Borlase suggests an explanation of these differences, and demonstrates a spontaneous perception of the influence of coastal physiography on variability of Run-up.

Borlase explains the wave direction by a reflection on Cape Lizard: his analysis may not be fully reliable, as at the Mount, the eastern direction reaches the coast after about only one kilometre, and at Newlyn the true south direction should cut across the Cornish coast. In fact it must have come from the south-east and south-south-east direction. Borlase also mentions an attempt to measure the speed of the flow in Gwavas lake (the name applies to the roadstead of Newlyn) as a Ketch of War threw its log and measured a speed of seven knots: $12.96 \mathrm{kph}$.

No damages were done to the fishers' boats, neither does Borlase mention any inundation of the shores: it appears that the tide was low enough to prevent the run-up to reach higher than the high tide mark. or to overflow the embankments: this is reconfirmed by the description of the boats being "hurried back again through the gap or mouth of the pier with incredible velocity: when they had gone off as far as the reflux determined, they were carried in, and out again". The true safeguard of the Cornish harbours may well have been that the tide was already low enough after two hour of ebbing.

\subsection{Devonshire}

\subsubsection{Plymouth}

John Huxham (Huxham, 1756) reports the event at the limit between Cornwall and Devon, on the sites of two ferries crossing the rias on which the town and harbour are established:

At the Oreston Ferry, located east of Plymouth, upstream from the harbour of the time, an initial drawdown of 1.22 to $1.52 \mathrm{~m}$ occurred, leaving the ferry-boat lying on the mud of the bottom. It was followed by a swell of $1.83 \mathrm{~m}$, giving the wave a run-down to run-up amplitude of $3 \mathrm{~m}$ : The wave did not break, but from the given time, about 4 PM, it was indeed the tsunami. And the phenomenon was indeed repeated a few times, the period being maybe a quarter of an hour.

The second ferry was at Cremyl passage, on a bottleneck of the river Tamar, west of Plymouth, and the border between Devonshire and the Duchy of Cornwall. The wave did not break there either. In Stonehouse lake, one of the branches of the ria, close to Cremyl, the wave developed into a true breaking bore. The tidal currents in Cremyl were deemed dangerous, and Huxham's words "tearing up of mud and sand bank in a very alarming manner" were cited by Dawson et al. (Dawson et al., 2000), accounting for the deposit of sedimentary bodies by such tsunami.

Huxham wrote this letter before he knew of the earthquake in Lisbon, and owns up to his ignorance of the cause. He was aware of observations done elsewhere by some correspondents or published in journals, and emphasizes the problem of the time of the events reported: 
"at Portsmouth, Holland, in Ireland, Germany, \&c. the waters were so strongly agitated on the very same day, it roused my attention greatly, though I am quite lost in conjecture of the cause. // it happened not here till about 4 p. m., at Portsmouth about 11 a.m., in Holland about 11 a.m., at Kinsale, \&c. in Ireland not till 3 or 4 a.m."

Paradoxically, morning in the eastern Channel and North Sea, against afternoon to late afternoon to the west of the British Isles (Cornwall, Devon, Ireland). The discrepancies were not yet understood as differences in the medium of transmission (solid crust against water) of waves caused by the same event.

\subsubsection{Dartmouth}

Dartmouth is in South-Devon, about $40 \mathrm{~km}$ east of Plymouth. The report (Holdsworth, 1756) was compiled five month later than those already discussed. The evidences presented are difficult to analyse :

"...there was a surprising agitation in the waters about nine in the morning / / there was a great and sudden swell // the boats, riding near the mouth of the river, tumbled and tossed as if they would have leaped into each other; and two of them broke loose from their moorings. // though it was four hour ebb, the water rose as high, or higher than they usually do on the highest spring tide. This violent motion lasted about three quarters of an hour, and then the waters fell ever since without any perceivable alteration..."

The time ascribed to the water agitation, about $9 \mathrm{AM}$, is earlier than the earthquake in Lisbon, which took place between 9:30 and 9:45. The longitude difference between Lisbon and Dartmouth does not warrant such a difference in local (solar) time: and the time should be later in Dartmouth than in Lisbon. If the water agitation in Dartmouth happened in the morning, this report can only refer to a water effect, in the estuary, despite the reference to the tide level : But the inquiries were conducted four or five months after the facts, and the memory of the witnesses must be questioned.

\section{France: Brest}

The claim that the earthquake was felt on the coasts of Brittany is not convincing, for want or particulars. Observations published in French gazettes or kept in Archives only deal with the agitation of waters caused by the crustal long waves. The only one worth examination (Abeille, 1756) deals with the harbour of Brest, in Brittany:

"The earthquake has been felt, more so on the Coasts than in Brest: it was on the $1^{\text {st }}$ of November, at nine in the morning, it was very slight, as it was only felt by a small number of people : but on the same day, and at the same hour, waters suddenly rose to a three feet height in a new Basin which they dig at present // at the foot of Saint-Magdelaine's mount. these Waters disappeared on the instant. Five minutes later they reappeared at the same height, and disappeared in the same way as the first time"

The wording so convoluted as to be almost impossible to interpret. The basin under excavation became the back-end of basin 3 of the arsenal, in the area of Pontaniou. Upon reading, one gets the impression that $0.98 \mathrm{~m}$ of water suddenly exuded from the bottom of the basin, and were reabsorbed quite as quickly! This is of course impossible: the water came from the river Penfeld, breaking through or overflowing any kind of cofferdam isolating the basin. This could only be the tsunami if the reported time was wrong, but this report describes the hydraulic perturbation brought about by crustal low frequency surface waves. Obviously, the north-west corner of the Galician coasts efficiently shielded France from the tsunami wave. 


\section{Iberian Peninsula}

\subsection{Galicia: A Coruña, Corcubión}

Abbot Frishman's consular letter from Coruña is not widely known, due to its diplomatic status: few copies were distributed among the Ministries in Paris: A dispatch in the JHMT (JHMT, 1756b) must derive from Abbot Frishman's letter.

"At ten in the morning // the Earth Shook // The tide, which was at twelve, was higher than it should have been // From one PM to one and a half, the sea rose and fell seven times. The same thing was observed during the whole ebbing of the tide; The water rising and falling as much as six feet of height." (Frishman, 1755)

The tsunami reached Coruña about three hours after the earthquake happened. It also provides us with an estimate of the amplitude, $1.95 \mathrm{~m}$. There may be a run-up component in this height, as Coruña harbour is situated on a rather jagged, indented coast. The frequency of the fluxes and refluxes (seven in half an hour) shows that the tsunami wave was already quite perturbed by diffraction and multiple reflections along the coasts when it reached the area. The anomalous wave ended only on the morning of November $2^{\text {nd }}$. The JHMT introduces some confusion by overrating the swelling of the sea during the quake itself, while Frishman, at that moment, mainly mentions the whirling of the waters.

The tsunami is also mentioned at Corcubión, about $75 \mathrm{~km}$ south-west of Coruña, with a crest to trough amplitude slightly higher than the tidal range (Lemaur, 1755, in Pérez-Gómez., 2009). The travel time may have been only $1 \& 1 / 2$ hour.

\subsection{Portugal}

\subsubsection{Oporto}

The November 1st, 1755, tsunami in Portugal has been re-discussed by Baptista \& Miranda (Baptista \& Miranda, 2009), and we can add little to their assessment, as the available primary sources are the same. Most documents on November $1^{\text {st }}$ in Porto originate from the British community, and were printed in British journals. Wolsall (Wolsall 1756) states that this town "quite escaped" the earthquake and tsunami: perhaps only by comparison to the major destructions undergone by Lisbon. The estuary of the Douro river has an east-west orientation, which did not favour the funnelling of the tsunami wave towards Porto. The accounts provide us with an estimated range for the wave height of 1.22 to $1.83 \mathrm{~m}$. (Philos. Trans., 1756b; Philos. Trans., 1756d; Gent's Mag., 1756a): also, three of these original documentary sources (Gent's Mag., 1756a ; Philos. Trans., 1756c ; Muysson, 1756) state that two ships, which were going out of the harbour, were forced in again, above the bar which crossed the estuary. This may require the maximum water height cited by the authors, but it implies that this estimate describes the run-up: the simple amplitude at shoreline may have been slightly less. The Philosophical Transactions letter LIX-VIII (Philos. Trans., 1756b) gives a wave period of $15 \mathrm{~min}$, while Letter LIX-XI (Philos. Trans., 1756d), giving only one minute, must be erroneous on that notion.

\subsubsection{Setúbal, Portimão, Faro}

Most classical documents on the tsunami in Setúbal post-date some of the French diplomatic letters (Partyet 1755a). These diplomatic letters are not evidences from a true witness, as he resided in Madrid. Later, these indications found their way into the French Journals (JHMT, 1755 ; Merc. Fr., 1755), and maybe to the British Journals, as it took the British Special Envoy two weeks to send news to his country. 
The annotations of the Priest of Saint-Julian Church, (in Gardi et al. 2009), clearly states that the tsunami waves inundated the village three times, but the amplitude of the waves is not mentioned.

Tedim Pedrosa \& Gonçalves (2008) mention that in Ferragudo and Portimão, Forte São João do Arade was completely washed out while on the opposite bank of the estuary, Fortaleza Sta Catarina was also damaged; and the Convento de São Francisco was completely destroyed. The sources given are the Dicionário Geográphico, a survey registered in 1758, and a book (J.B. Lopes, 1841?) both unknown to us. The evidences that the run-up reached $20 \mathrm{~m}$ above average sea level (a.s.l.) are not reliable: damages to fortresses could have been the collapse of pieces of the walls, which might have been triggered by the tsunami if the rock or lower levels of masonry were already weathered by salt-water alteration and undermined by the waves : but it would not demonstrate any level of run-up.

Actually, Fortaleza Sta Catarina is still in existence, if no longer in any military use, and Forte São João was sometimes a residence of the poet Joaquim José Coelho de Carvalho (1852-1934). The buildings of the Convento de São Francisco are indeed in a state of advanced ruination, as the result of fire in 1884, but the original mannerist period walls are still standing. Any $18^{\text {th }}$ century repairs or re-building cannot be estimated, but damages could have been caused by the earthquake itself, as much as by the tsunami. However it appears that the monastic community may have been dissolved as a consequence of the earthquake and tsunami.

Most documentary sources assign to Faro the same fate as Setubal (Partyet, 1755a; Merc. Fr., 1755; Lond. Gaz., 1755): but the evidences are not clear and mostly hearsay: they provide no description, nor even the name of a building having existed in the allegedly destroyed town, and are unable to attribute the damages specifically to the earthquake or to the tsunami. In a recent article, Baptista \& Miranda (Baptista \& Miranda, 2009), citing a manuscript by Castro (1786), advocate that the city and harbour of Faro underwent nothing worse than a strong spring tide... though at a moment when they expected half-tide, of course. The tsunami was felt, but it was not that destructive: no one would have dared negate the destructions if it had been common local knowledge that Faro had indeed been washed away. When Castro wrote, thirty-one years after the event, there was no place left for hearsay, as real travellers had revisited the place.

\subsection{Andalusia}

\subsubsection{Cadiz}

The primary record of the tsunami in Cadiz was extensively discussed in Blanc (2008), so that the present purpose is only to consider how additional sources can now affect our previous conclusions.

A London Gazette (Lond. Gaz., 1755) dispatch dated $4^{\text {th }}$ November, published on November $29^{\text {th }} 1755$, dealing with Cadiz may derive from a letter written by the French Consul in Cadiz (Desvarennes, 1755) on the same day. Both may originate from an official statement by the Governor of Cadiz, which he must have issued after consultation with Godin.

An anonymous 16-pages brochure in French, titled "Relation du Tremblement de terre arrivé a Cadix le premier de Novembre 1755", now remains in the library of the University of Göttingen founded by the Elector Georg August, Duke of Hanover and King of Great Britain as George II. Bearing the eighteenth-century library stamps on verso of first leaf, "Ex BibliotheCA REGIA ACAD. GEORGIAE AUG", registered as 8 MIN III, 8655, it entered the library in 1773 as part of the private collection of Gottfried Achenwall (1719-1772), an historian and statistician in the University of Göttingen (personal communication from Frau Cornelia Pfordt, Librarian in the Niedersächsische Staats- und Universitätsbibliothek Göttingen). This text 
is obviously contemporaneous with the earthquake. The photocopy now in my institution was probably obtained there during the $1980 / 90$ 's, by the late Jean Vogt, then very active in the research of original documents on historical seismicity.

This brochure (Anonyme "de Göttingen", 1756-1772) reports that the initial wave hit the town-walls a little below the string-course of the Parapet: it validates the testimonies of Godin (Godin, 1755) and Ulloa (Ulloa, 1756b) by wording differently the same observation (Figure 1) : the water-height of the tsunami at shoreline was $5.85 \mathrm{~m}$ above the marine zero datum, $3.85 \mathrm{~m}$ above mean sea-level. and $2.5 \mathrm{~m}$ above the expected high tide at noon on that day, November $1^{\text {st }} 1755$ (Blanc, 2008).

At variance, such a statement as "considering the height of the sea when in its natural state, at mid tide, the increase caused by the earthquake must have been of 36 feet" $(11.69 \mathrm{~m})$ remains puzzling. The same estimate is found in Ulloa (1756b), but it is referred to the High Equinoctial Spring Tide level, locally $2 \mathrm{~m}$ above average sea level (natural state, at mid tide). No justification is given of this height estimate, contradictory to facts: the town was not submerged. The sentence "The parapet // was broken in flush with the course string, in 6 different places, which the waters used as so many inlets" clearly shows that the water did not overflow the whole circumvallation, but only breaches in the Parapet, so described: "One // was of 85 ells, \& another of 55, the 4 others // smaller" (the French word for "ell" was the usual translation for the Spanish Vara de Burgos, the Spanish standard for a somewhat shorter equivalent to the Yard). A run-up height of $11.7 \mathrm{~m}$ would not allow for the frantic run of the populace from one town gate to the other, described by Governor Antonio de Azlor (1755, in Blanco-Moyano, 2005): "It is not possible to express the clamour, the tears and the prayers which were heard in the town, during the three hours that lasted the unusual motion and the threat of the sea". As all the streets would have been immediately drowned, and the houses foundered, that noise would have been soon put to end.

The account of the arrival and timing of the tsunami is corrupt: the time of arrival of the first positive wave is correct, but the detail of the different assaults by the successive wave has been badly transcribed:

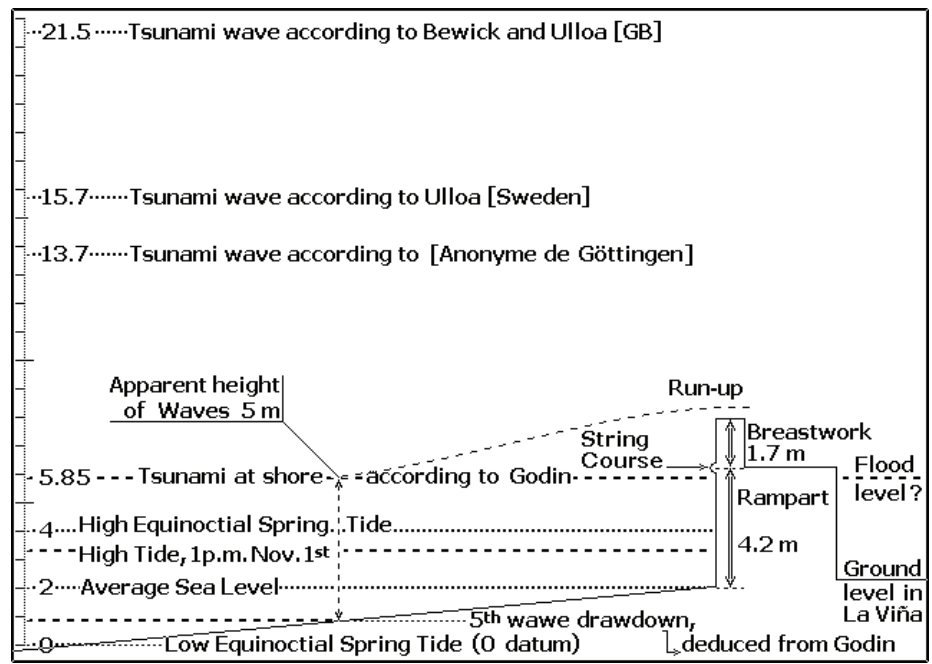

Fig. 1. Comparison of the normal scale of hydrographical levels in Cadiz (0-4 m) and wave setting proposed by contemporary authors. (Modified from Blanc, 2008). 
"The $1^{\text {st }}$ at 11 hours 10 minutes // The $2^{\text {nd }}$ at 11 hours 30 minutes // The $3^{\text {rd }}$ at 11 hours 33 minutes // The $5^{\text {th }}$ at 1 hour 10 minutes // The $6^{\text {th }}$ at 1 hour 50 minutes." Any mention of the fourth wave is lacking, and the intercalated comments and explanations. We need not alter the lag between the $1^{\text {st }}$ and $2^{\text {nd }}$ wave, nor between the $5^{\text {th }}$ and $6^{\text {th }}$ : they correspond to the only data really clear in the timing by Ulloa (1756a), showing that the period increased from 20 to 40 minutes in six phases. The arrival of the third wave can have taken place at 11 hours plus something, but not three minutes only after the second. It is therefore between "11 hours" and "33 minutes" that the restoration which these data require must be placed. Admitting that the indication "33 minutes" is correct, it must refer to the fourth assault, but it should follow "12 hours". And $12 \mathrm{~h} 33$ for this fourth wave is acceptable, the table by Godin (1755) gives $12 \mathrm{~h} 35$. One may then transfer a similar difference for the third assault, which would have taken place one or two minutes before the 12 hours of the table of Godin, be it $11 \mathrm{~h} 58$ or $11 \mathrm{~h} 59$. This restoration bears on only one line (or two half-lines) in table 1 , and gives an ideal damping curve. The difference with the timing by Godin regularly increases, from 0 to $5 \mathrm{~min}$ for the five first assaults, but only from 0 to $3 \mathrm{~min}$ if we consider the duration of periods : just slight differences in the rounding of the number of seconds! This also allows us to understand how the damping tables diverged in Ulloa's apocryphal communication to the Royal Society (Ulloa , 1756a), which is inaccurate because of a poor restoration, and in the Acts of the Royal Academy of Sciences of Sweden (Ulloa, 1756b), where they did not detail the periods, for want of a consistent table (Blanc, 2008).

\begin{tabular}{|c|c|c|c|c|c|}
\hline Author & Godin, 1755 & Ulloa, 1756a & Ulloa, $1756 b$ & $\begin{array}{c}\text { Anonyme de } \\
\text { Göttingen } \\
\text { 1756/1772 }\end{array}$ & $\begin{array}{l}\text { proposed } \\
\text { restoration } \\
\text { (this chapter) }\end{array}$ \\
\hline $1^{\text {st }}$ wave & 11 h 10 & 11 h 10 & $11 \mathrm{~h} 10$ & 11 h 10 & 11 h 10 \\
\hline $2^{\text {nd }}$ wave & $11 \mathrm{~h} 30 \quad 20 \mathrm{~min}$ & $11 \mathrm{~h} 30 \quad 20 \mathrm{~min}$ & \multirow{4}{*}{$\begin{array}{l}\text { 'til two hours } \\
\text { after noon, the } \\
\text { sea rose six } \\
\text { times... }\end{array}$} & $11 \mathrm{~h} 30 \quad 20 \mathrm{~min}$ & 11 h 30 \\
\hline $3^{\text {rd }}$ wave & $30 \mathrm{~min}$ & 11 h 50 & & 11 h 33 & 11 h 58 \\
\hline $4^{\text {th }}$ wave & $12 \mathrm{~h} 35 \quad 35 \mathrm{~min}$ & $12 \mathrm{~h} 30 \quad 40 \mathrm{~min}$ & & ------- & $12 h 33$ \\
\hline $5^{\text {th }}$ wave & 13 h 15 & 13 h 10 & & 13 h 10 & 13 h 10 \\
\hline $6^{\text {th }}$ wave & about 14 h 00 & $13 \mathrm{~h} 50 \quad 40 \mathrm{~min}$ & about $14 \mathrm{~h} 00$ & $13 \mathrm{~h} 50 \quad 40 \mathrm{~min}$ & 13 h 50 \\
\hline
\end{tabular}

Table 1. Periodicity of the tsunami waves in Cadiz on November 1st, 1755.

But it corroborates our recognition of the brochure as being closest to the source of the letter of Ulloa which was summarized and printed in the Swedish text in 1756. Not a copy, it is an earlier state of the text, most probably the same that Bouguer read at the Royal Academy of Sciences of Paris on December 3rd 1755. Whoever edited it was honest, and did not alter the description or introduce uncontrolled ideas. It may have been printed up to fifteen years after the event, but the data carried by the accounts mentioned (Godin 1755; Godin fide Martínez Solares et al 2004; Ulloa 1756a; Ulloa 1756b; Anonyme de Göttingen 1756/1772) complete each others and demonstrate their common origin. They compose a consistent corpus of what happened in Cadiz on November 1st, 1755. 


\subsubsection{Gulf of Cadiz}

The coast of the gulf of Cadiz, on both side of the Portuguese-Spanish border, is a low coastal plain, some miles wide, in front of higher ground. There are no clear descriptions of tsunami damages to the towns: The description by Ramos Dávila (in Blanco, 2005) shows that the towns stood on firmer ground that the marshlands, only mentioning the inundations of the first streets in Huelva: "Three quarters of an hour after the earthquake ended, the sea was furiously agitated, and the waters pushed towards the coast // the river came out of its course, sending waves to the first streets, inundating the plains, and with much damage to the boats". But the fishermen's cabins and salting sheds, on the shore, were destroyed, and people were drowned: from three hundred (Anonyme de Göttingen, 1756/1772) to one thousand (Ramos Dávila). This cannot be considered as a proof that the wave was so very high, since the speed of the tsunami (a few tens of km per hour) and a ventral segment several $\mathrm{km}$ long in the direction of the wave movement, account for the destruction of all but the strongest buildings within the reach of the wave. Lima et al. (Lima et al., 2010) mention a possible run-in of $11 \mathrm{~km}$ from the coast line to Huelva (town centre): it must be pointed out that this occurred through the estuary and valleys of the rivers Odiel and Tinto, rather than on the flats themselves. In the 18th century map reproduced in their article, the salt-marshes are deemed liable to flooding: only more so to tsunami-flooding! But from the map itself, the run-in on the salt-marshes appears to have been little more than one league.

Both the London Gazette and the Gentleman's Magazine mention the periodical nature of the phenomenon: "... at Port St Maria's, the Sea had rose eight several Times, and frightened all the Inhabitants out of the Town"; (Lond. Gaz., 1755; Gent's Mag., 1755). Unfortunately they forget to mention the unit applied to the measurement of the amplitude at shore: "eight" according to the London Gazette, "8" (Arabic numerals) in the Gentleman's Magazine. Admitting it was the foot, the conversion may be from 2.23 to $2.60 \mathrm{~m}$, considering the range from the Spanish to the French units: This does not differ much from what Godin (1755) reported in Cadiz, $2.51 \mathrm{~m}$. As Puerto de Sta Maria is on the mainland, people were able to flee to higher land, while the Gaditans could not.

Many French documents describe Conil as having been ruined: this may be true, but no real evidence is supplied, and none of these are true primary documents.

French dispatches have no value on Gibraltar, a British harbour, on which only English accounts can be relevant: the falling of the Rock on the town was just wishful thinking from enemies (JHMT, 1756a). The indication of water swell and recess of $1.83 \mathrm{~m}$ (Gent's Mag., 1756a) must be a crest to trough figure: the Strait is close to $900 \mathrm{~m}$ deep, just South and East of Gibraltar; the wave, travelling from west to east, was loosing its amplitude: and no damage or loss are properly described.

\section{Africa}

\subsection{Morocco}

The contemporaneous accounts on the tsunami of November 1st, 1755, have been reexamined recently by Kaabouben et al. (2009) and by Blanc (2009), in a critical analysis of documents, closest to primary sources, having reached France and England within about two month of the event. Almost everywhere in Morocco the amplitude of the tsunami has been vastly overestimated : In Tangiers and Mazagão the exaggeration may have been six to ten-fold. In Tangier a conservative estimate is that it was the same as the measurement 
given by Louis Godin (1755) for Cadiz, i.e. $2.5 \mathrm{~m}$ above the calculated astronomical tide or a crest-to-trough double amplitude of $5 \mathrm{~m}$. Kaabouben (Kaabouben et al. 2009) cite a height of $2.72 \mathrm{~m}$ in Assilah from the Gentleman's Magazine.

A parallel drawn between the event in the two countries, showing that there were no scale differences, justifies this conclusion: [1] in Morocco, Mazagão was surrounded by the tsunami waters, and the outer defences were swept away ; in Andalusia, Cadiz is naturally surrounded by the Atlantic Ocean and the Puntales Basin, but the causeway, on the tombolo leading to the isle of León, was dismantled. [2] also close to Cadiz, on the same causeway, travellers going to or leaving the town were carried away from the road and drowned; Near Salé, a caravan following a track, either on the shore or along the Bou Regreg estuary, was engulfed by the tsunami.

As in the case of Cadiz, we only comment on reports not taken into consideration previously.

\subsubsection{Ceuta (Spanish enclave)}

For Ceuta we find the same account both in the JHMT and in the Gazette de Cologne: "... The sea swelled to the height of seven feet, \& a quarter of an hour later, in came down so much, that great quantity of boats and fish remained dry on the sand. These fluxes and refluxes followed alternately, until the next morning: but at two after-noon they began to decrease progressively." (JHMT, 1756b). These accounts are the only one for this place in French Journals, as they are copies of each other. The water height is about the same as described in Gibraltar, but for possible differences in units. Applying the Spanish official units of Burgos, the measurement given is equivalent to $1.95 \mathrm{~m}$. As in Gibraltar, this must be a crest to trough amplitude: the Strait deepens from west to east, and reaches about $900 \mathrm{~m}$ just North of Ceuta, so that the amplitude of the waves decreased : accordingly, no damage or loss are described.

\subsubsection{Tangiers, Asilah, Larache, La Mamora}

Kaabouben et al. (2009) recently cited the very short mention of Assilah in the Gentleman's Magazine for Dec. 1755: "At Arzilla in Barbary the water rose nine feet, and a settee of the town foundered..." (Gent's Mag., 1756a). This despatch, purportedly written on November $7_{\text {th }}$ in Gibraltar, may have been the very first hint of the occurrence of a tsunami in Morocco to reach Europe, and it did not even acknowledge the earthquake.

This estimate of the water height at shoreline $(2.73 \mathrm{~m})$, compares well with the figure given by Godin in Cadiz, within a $10 \%$ error: we cannot expect better, due to the lack of consistency of the systems of measure used. It also confirms our opinion that in the London gazette and Gentleman's Magazine reports (Lond. Gaz., 1755; Gent's Mag., 1755) on Puerto de Sta Maria, the intended unit after "eight" or "8" was indeed the foot (in that case with a $12.5 \%$ error). Both these estimates endorse our conclusion that the tsunami was the same in Morocco as on the south-west coasts of Spain (Blanc, 2009).

We do not understand what is the foundering of a settee: the present meaning of the word makes no sense in this context.

Concerning Tangier, the legend of sea-water desalinated by a tsunami (Gent's Mag., 1756a; JHMT, 1756b), already commented on (Blanc 2009), was spreading as early as November $20^{\text {th }}$. It must be discarded as impossible in term of Physics or Chemistry. The estimate of a wave height of $15 \mathrm{~m}$ and overflowing the ramparts is not better justified. The Gazette 
d'Amsterdam (Gaz. Amsterdam, 1756) conveys no news not found elsewhere, except that the wording implies that the tsunami occurred on November $18^{\text {th }}$, but the printing of this Gazette is too late to give it any authority. Damages are often mentioned in Larache and La Mamora (Kenitra), without any detail liable to analysis.

\subsubsection{Salé}

The tsunami in Salé has been discussed both in Kaabouben et al. (2009) and in Blanc (2009). The testimony of the Gentleman's Magazine, "A caravan with 200 persons going from Sallee to Morocco along the coast, was destroyed by the sea, which rose to a prodigious height almost in an instant; and another caravan, with yet a greater number of persons, going from Sallee to Fez, was destroy'd by the sudden rise of the inland rivers..." (Gent.'s Mag. XXV, Supp. 1755, p.587), appears to double the number of caravans carried away by the tsunami. We do not exactly know if the caravan was washed away on a truly coastal tract or along the estuary of the Bou Regreg.

\subsubsection{Safi, $\mathrm{S}^{\text {ta }}$ Cruz de Agadir}

The documents considered in Blanc (2009) all report heavy damages in Safi and in Sta Cruz (Agadir), ranging from several houses destroyed to many houses and buildings overturned, but the image of the destruction remains extremely blurred. The French documents did not even grant a separate paragraph to these harbours (Blanc, 2009), while the British reports did not consider $S^{\text {ta }}$ Cruz at all.

Some Dutch primary sources show a very different image: In a letter written on May $5^{\text {th }}$, 1992 to A. Levret, the late J. Vogt mentioned that he had found in the Leidse Courant (Leidse Courant, 1756b; a Dutch newspaper issued thrice a week or so) that the earthquake did no more damages in Sta Cruz de Agadir than in Tetuan; that it was already known that it had caused no damages in Safi and that the tsunami only damaged a few boats there. The Friday, January $9^{\text {th }}$ issue of this newspaper reports that nothing happened: "By a ship, which arrived in 22 days from Sta-Cruz in Barbary in England, we have news of Dec. $4^{\text {th }}$, "according to which not the slightest damage has been felt from the earthquake there, and also that no one knew of a catastrophe to have happened on those shores..." (Leidse Courant, 1756a) The Dutch captains certainly had the scientific rigour to deliver faithful testimonies. The position of these two harbours is not quite in direct line from the likely positions considered for the epicentre and origin of the tsunami, so that it should not have been stronger than in Coruña or even the Cornish Mount's bay.

\subsection{West Africa: Coast of Guinea}

An anonymous letter to the Académie Royale des Sciences de Paris, dated Dec. $15^{\text {th }}$, read by Duhamel on March 24th 1756 , mentions coastal freshwater lagoons, on the West-African coast, where the Slavers from Nantes used to take in fresh water before crossing the Atlantic towards the Caribbean : "The same event occurred on the same day on the coast of Guinea, according to what told us Captain Charlery, who is from your shire, who commands a Slaver from Nantes, and who has been happy enough to escape in the Channel from 5 English ships cruising there. All the lagoons at Cape ****, were they used to take water, happened to be filled by the sea." (Anonyme "lu par Duhamel", 1756). Captain Charlery reported only the fact that the water had become brackish. This was due to the tsunami, as 
agitation by crustal low frequency waves could have only caused a loss of freshwater from the lagoons, not an input of saltwater. The name of the Cape marking the position of the lakes is omitted, due to the naval war between the French and English : the French captains tried to avoid giving to the English information which could have allowed them to lay in ambush, had the Martinique mail been caught: a witness to this is the fact that this same boat had had to escape five English men-of-war cruising in the channel of St Lucy. These lakes were anywhere on the coasts from Senegal to Liberia, so as to shorten as much as possible the duration of the crossing of the Atlantic, during which they would live on that water. The vague location prevents any speculation on the height of the tsunami waves : but this account is the most southerly one we know of, on the coasts of the Old World.

\section{Macaronesia}

\subsection{Azores: Terceira}

A short dispatch published in the Leidse Courant (Leidse Courant, 1756a) mentions that in the Azores "only slight shocks of earthquake had been felt, but that the Ebb had been strong at that moment in the harbour 200 that it was almost possible to see the Anchors of the ships on the bottom". In the description of the drawdown, it is difficult to understand why the number "200" (Arabic numerals) in mentioned after the word "haven", unless the typographer forgot to mention a unit, likely the foot : in which case it could be an horizontal distance of drawdown of $61 \mathrm{~m}$.

\subsection{Madeira: Funchal, Machico, Porto da Cruz}

Two letters to the Royal Society (Heberden, 1756; Chambers, 1756), dealing with the tsunamigenic earthquake in Funchal and the island of Madeira, complete one another. The earthquake was felt at 9:18 AM according to the timing by Chambers, in accordance with the time-record in the Astronomical Observatory in Cadiz, 9:52, and with the 10 $37^{\prime}$ difference in longitude. It was shorter in Madeira than in Lisbon. The tsunami took place $1 \frac{1}{2}$ hour later : 11:00 (Heberden) or at 10:48 (earthquake time from Chambers plus travel-time from Heberden).

The first wave allegedly reached an amplitude of $5.64 \mathrm{~m}$ in Funchal (from half-ebb level to 15 feet above high water mark), though the harbour faces to the South, while the wave came from the North-North-East. A contradiction is that both accounts mention that the inundation was worse to the North and East of the island, causing damage and loss of property, these coasts being in the general direction of origin. The losses described in Porto da Cruz are loss of goods (grain, pipes of wine) or equipment (distillation stills): the Madeira wine production being mainly exported, these pipes of wine were stored on the quays, or in sheds with direct access, and the stills must have been installed there too, unless they had just been unloaded from some ship and waited for transportation further inland. Heberden insists that the subsequent waves only oscillated between high and low tide levels, and this observation must be reliable : witnesses must have been relieved that no reinundation happened. : this means that the amplitude of the second and subsequent waves was about $1.07 \mathrm{~m}$, or $2.13 \mathrm{~m}$ peak to trough, but it implies that the fist wave in Funchal was heavily overestimated by Heberden : it is doubtful that it could have been five time higher than the subsequent ones: the damages reported do not warrant as strong a wave as in Portugal or in Spain. Two metres may be an proper estimate of the amplitude at shore. 


\subsection{Canary Islands: $S^{\text {ta }}$ Cruz de Tenerife}

"In a letter from Sta-Cruz de Teneriffe on Nov. 12, no unfortunate tidings is ever mentioned about the earthquake..." (Leidse Courant, 1756a) : The wording of this letter implies just that : there was no damage in Sta Cruz de Tenerife, and no one was endangered. It does not mean that the tsunami was not observed, but it is strictly impossible to extract anything more accurate.

\section{Caribbean Islands}

\subsection{Barbadoes}

News from Barbadoes arrived rather quickly in Europe : the first mention of the place by the Gentleman's Magazine (Gent's Mag., 1756b) shows that the dispatch arrived probably early in December. Those early news contain very little quantifiable details.

Overall, we come up with three wave amplitude evaluations :

The JHMT (JHMT, 1756c) puts forward an estimate of five British feet $(1.52 \mathrm{~m})$ : British, because no Frenchman could have made measurements and reported to a French journal, from an English colony, while the two countries were at war: this must originate from an English dispatch passed to France through neutral ground (the Netherlands or a German harbour).

Captain Affleck (Affleck, 1756) gives an estimate of 3.66 m : "at Antigua, Nov. 1, 1755 / / The tide rose here twelve feet perpendicular several times, and returned almost immediately : the same at Barbadoes." showing that he was not in Barbadoes at the time.; then, with a second, more reliable, testimony, he re-assesses the amplitude in Antigua to have been $1.52 \mathrm{~m}$ : thus, "same in Barbadoes" meant nothing more than that the tsunami was observed. The report by William Hillary is somewhat convoluted : "At 20 minutes after 2 o'Clock after Noon, above an Hour after it was High-water there, the Sea suddenly flowed and rose more than two Feet higher than it does in the highest Spring Tides, and in three Minutes time it ebbed so as to be as much lower than the usual lowest Ebb" (Hillary, 1756). The total crestto-trough height which we can compute from this indication is two feet of positive run-up plus the usual tide range plus a draw-down similar to the run-up. As the Atlantic tidal range on the Caribbean Islands is about $30 \mathrm{~cm}$, this figure turns out to fit the JHMT estimate of $1.52 \mathrm{~m}$.

\begin{tabular}{|c|c|c|c|c|}
\hline & $\begin{array}{c}\text { Gent's Mag., } \\
1756 \mathrm{~b}, 589-590\end{array}$ & $\begin{array}{c}\text { JHMT, 1756c, } \\
463-464\end{array}$ & Affleck, 1756 & Hillary, 1756 \\
\hline Time of arrival : & 2 PM & 2 PM & & $2: 20$ PM \\
\hline $\begin{array}{c}\text { Peak to trough } \\
\text { amplitude : }\end{array}$ & $\begin{array}{c}\text { over wharfs into } \\
\text { houses }\end{array}$ & $1.52 \mathrm{~m}$ & $3.66 \mathrm{~m}$ & $1.52 \mathrm{~m}$ \\
\hline Duration : & & $\begin{array}{c}8 \text { hours, } \\
64 \text { periods. }\end{array}$ & & every $5 \mathrm{~min}$ \\
\hline
\end{tabular}

Table 2. Comparison of available tsunami parameters in Barbadoes.

A tsunami wave causing a run-up little more than $61 \mathrm{~cm}$ high and a crest to trough amplitude of $1.52 \mathrm{~m}$ may be enough to make a strong impression on witnesses used to a tidal range of $30 \mathrm{~cm}$. The considerations on the period of the wave train are less clear, such a sentence as "the Times between its Ebbing and Flowing decreased, so as to be a little longer" being somewhat contradictory! It only appears that the period increased from 5 to $20 \mathrm{~min}$ between 2:20 PM and 7 PM. 


\subsection{Martinique}

True primary documents for this tsunami in Martinique are not numerous, nor widely known. Two excerpts of letters to the Académie Royale des Sciences de Paris, read there on January 28 $8^{\text {th }}$ and March 24th, 1756 , were recorded in the Procès-Verbaux (Lettée, 1756 ; Anonyme lu par Duhamel, 1756): no doubt is possible as to their contemporaneous character. A third contemporaneous document, published by the Royal Society (Affleck, 1756), mentions Martinique in two lines: but it cannot be considered as a true primary testimony : the author was certainly not on the spot at the time of the event.

We also consider three local documents printed in the middle of the 19th century, the authenticity of which relies on the archaic style and spelling. The first was published in Saint-Pierre in 1846 by a Martinican historian, Sidney Daney de Marcillac. In the pages concerning the earthquake and tsunami (Daney, 1846), the form of the imperfect tense is modern (-ait, -aient, not the archaic-oit, -oient), but some word are spelled so as to drop the mute "T" at the end of nouns or adjectives such as "savans", "environnans" and "événemens", an obsolete spelling in the 19 $9^{\text {th }}$ century, showing that Daney borrowed the ancient text itself, not just from it. The same applies to an extract of a book by the sometimes mayor of SaintPierre, Dr Etienne Rufz de Lavison (Rufz, 1850), in which a similar archaic spelling of some words is observed : "instans" without a mute "T" ; "isle" instead of "île", absolutely obsolete in French in the 19th century ; or "appercevoir" with two "P". In this case also the forme of the imperfect tense was up-dated. Measurements are given in the old French units rather than in Metric units. This $18^{\text {th }}$ century text published by Rufz was later reproduced with the spelling of words fully corrected to more recent usage, but not the units (Ballet, 1896 ; Cottrel, 2003)

The letters recorded in the Procès-Verbaux clearly state that it was in the Cul-de-Sac de la Trinité that this tsunami was felt, and Rufz also insists that it was ignored everywhere else : "this event was little perceptible in Galion and not at all at Robert or at Ste-Marie, though la Trinité is only one league from Ste-Marie and Galion, and four from Robert." The bay of La Trinité in Martinique is funnel-shaped, oriented toward the North-North-East, between the North-East coast of the island and the North-West coast of the Caravelle peninsula, projecting at right angle from the main coast.

The time of arrival of the wave is not perfectly established: two of the witnesses suggest 2 PM and only the earliest one, 4 PM, local time, of course. Daney (1846) ascribes a four hours leg to the tsunami wave (towards $10 \mathrm{AM}$ at Lisbon, 2 PM in Martinique) but he omits the time lag between the European coasts and the lesser Antilles, which is at least $31 / 4$ hours. This cannot be part of a true primary report anyway.

The amplitude and drawdown show a similar discrepancy : the two late texts concur on the distance of withdrawal and on the amplitude of the fist wave: drawdown to half the distance of anchoring, i.e. 200 paces or $140 \mathrm{~m}$ (the French Pas being the length of a single step) and the amplitude $0.65 \mathrm{~m}$; while the documents contemporaneous to the event do differ by an order of magnitude, with a run-up of $0.975 \mathrm{~m}$ (Lettée 1756) to $9.75 \mathrm{~m}$ (Anonyme lu par Duhamel, 1756).

Had the amplitude been $9.75 \mathrm{~m}$, the descriptions would not just lament the loss of stored coffee, as reported by both Lettée (1756): "all the houses in the town were inundated of more than three feet of water, all the stores were filled with coffee, which was soaked, as a consequence it is spoilt coffee. "and Rufz (1850) : "this third instance, it broke open the doors of the houses, though well secured from inside ; the coffee which happened to be there were lost, and some people just escaped being submerged ;". 
Waves $9.75 \mathrm{~m}$ high would have only left the destruction of lives and village to mourn : towns hit by such waves in Sumatra on Dec. 26th, 2004 were merely reduced to parcellinglots, drawn on the ground.

\begin{tabular}{|c|c|c|c|c|}
\hline & $\begin{array}{l}\text { LETTÉE, } \\
1755\end{array}$ & $\begin{array}{l}\text { ANONYME lu par } \\
\text { Duhamel } 1756\end{array}$ & DANEY 1846 & RuFZ de Lavison 1850 \\
\hline Time & 4 PM & & \multicolumn{2}{|c|}{2 PM } \\
\hline Travel time & & & $\begin{array}{c}\text { "about four hours" } \\
\text { local-time lag omitted }\end{array}$ & \\
\hline $\begin{array}{c}\text { Drawdown } \\
\text { distance }\end{array}$ & & & \multicolumn{2}{|c|}{$1 / 2$ anchoring distance, $125 / 140 \mathrm{~m}$ ? } \\
\hline Drawdown & $6.5 \mathrm{~m}$ & & & \\
\hline Amplitude & & & $0.65 \mathrm{~m}$ & $\begin{array}{l}1^{\text {st }} \text { wave, } 0.65 \mathrm{~m} \\
2^{\text {nd }} \text { wave, } 0.49 \mathrm{~m} \\
3^{\text {rd }} \text { wave, } 1.30 \mathrm{~m}\end{array}$ \\
\hline Run up & $\begin{array}{c}0.975 \mathrm{~m} \\
\text { in houses }\end{array}$ & $9.74 \mathrm{~m}$ a. s. 1. & & $\begin{array}{c}3.9 \mathrm{~m} \text { above high } \\
\text { tides }\end{array}$ \\
\hline Run-in & $65 \mathrm{~m}$ & & & \\
\hline Period & $1 / 2$ hour? & & \multicolumn{2}{|c|}{$1 / 4$ hour } \\
\hline
\end{tabular}

Table 3. Comparison of available tsunami parameters in Martinique.

The last paragraph dedicated by J. Ballet to this tsunamigenic earthquake "In December we learned that a dreadful earthquake had thrown down on the same day the town of Lisbon, and many towns in Morocco, and had extended its devastations in the whole of Europe, in Africa, in Asia, in America, where the shock was felt as far as Boston" (Ballet, 1896) typifies the confusion prevailing from the mid-18 th to the mid-20 $0^{\text {th }}$ centuries, between the November 1 st 1755 , tsunamigenic earthquake of Lisbon, the Rifian earthquake of November $18^{\text {th }} \& 19^{\text {th }}$, 1755 and the Cape Ann earthquake, in North America, also on November 18th, 1755. And Ballet adds Asia to make a good measure...

\subsection{Guadeloupe}

One reference to the tsunami in Guadeloupe island was only published 140 years later. This was in Sainte-Anne, the main harbour in the $18^{\text {th }}$ century:

"Guadeloupe had no event to record during the year 1755 / / Only, on November 1st, // On several point of the coast, there was a considerable withdrawal of the sea. In Saint-Anne, it ebbed down to the line of the keys which surround the roadstead, leaving only two channels, and, rising back with violence, it invaded the ground. In the borough, then considerable, of that parish, the waves came and broke against the porch of the church..." (Ballet, 1896)

The sea receded to a ring of tabular reefs surrounding the bay, the keys : their horizontal character is mostly determined by weak tides and agitation of the waters. In a recent paper (Roger et al., 2010) a height of $3.2 \mathrm{~m}$ a.s.l. is ascribed to the sill of the porch of the present chuch in Sainte-Anne, but it was built by the Architect Ali Tur in 1928 after the passage of a strong hurricane over Guadeloupe. The assumption that the elevation of the church did not change must be discarted, as banking-up of the ground must have taken place before erecting the new concrete Modern-Art style building: That the inundation allegedly reached the porch of the $18^{\text {th }}$ century church offers no run-up calibration. 


\subsection{Antigua}

The date to which captain Affleck (Affleck, 1756) refers this agitation of the water in the harbour of Antigua is indeed the $1^{\text {st }}$ of Nov., 1755. It has to be noted that there are essentially two different measurements of the amplitude of the wave in his testimony: in the first paragraph the crest-to-trough amplitude is given as $3.66 \mathrm{~m}$. But in the second paragraph he insists on the trustworthy character of a new witness and supplies us with the time of the tsunami, 3:30 PM, the period, $5 \mathrm{~min}$, the significant duration of the phenomenon, at least $2 \frac{112}{2}$ hours, but the crest-to-trough amplitude is reduced to $1.52 \mathrm{~m}$, the surface of the water quiet. And as indicated earlier, "the same in Barbadoes" only means that the wave was observed there. A short article from the Gentleman's Magazine (Gent's Mag., 1756b)do not add anything significant to the account of Capt. Affleck. A JHMT dispatch must have been picked from the British papers (JHMT, 1756b).

\subsection{Saint-Martin/ Sint Maarten; Saba}

The report of captain Affleck (Affleck, 1756) expresses nothing convincing in these islands : In Sabia, a measurement given is $6.4 \mathrm{~m}$, without even saying what the figure applies to. It might be a crest-to-trough, double, amplitude, but not without a very high degree of exaggeration. At St-Martin's, a ship anchored "in fifteen feet of water was laid dry on her broad side" : it did drag on its anchor under the heave of the tsunami, to upper ground, and was abandoned there on the water retreat. No indication of amplitude or run-up can be obtained from such fact.

The case of St Martin is complicated by the fact that Professor Winthrop (Winthrop, 1757) attributes the tsunami to the November 18 1755 "Cape Ann" earthquake. Reid (1914) clearly states that the November $1^{\text {st }}$ Lisbon earthquake was only known in New England when a ship arrived from Cadiz on December 15th, and the news appeared in the local Gazettes on December 22nd : Winthrop learned of the Lesser Antilles tsunami after the Cape Ann earthquake had taken place, and he attached the accounts of the sea movements to the earthquake he knew of, the North-American one. As he did not know of any other, he corrected the date from November $1^{\text {st }}$ to November $18^{\text {th }}$. The time of the tsunami in St. Martin's is given as 2:00 PM, but the Cape Ann earthquake was felt at 4:30 AM in Boston : If it had been on the same day, as the time-lag, in local time, between Boston and St Martin is about $35 \mathrm{~min}$, this would allow for a travel time close to 9 hours. A teletsunami could not have been that slow.

The data provided are not very reliable either : according to Winthrop, the initial drawdown was 5.5 to $7.3 \mathrm{~m}$. The positive height was only $1.83 \mathrm{~m}$, and this should be a run-up rather than amplitude at seashore. The negative wave may have preceded the positive one, but nothing accounts for the dissymmetry in the phenomenon: where did the water, removed from the shore by such a negative amplitude, go ? The initial drawdown of three or four fathoms is over-evaluated. If the Cape Ann earthquake had been strong enough to cause such waves, the coasts of New England should have been devastated :

One entry in the JHMT (JHMT, 1756b) attributes a tsunami to the November $18^{\text {th }}$ Cape Ann earthquake : "On November 18th, the town of Boston suffered several shocks, \& and a great number of chimneys \& roofs of houses fell. During this quake, the waters raised everywhere suddenly of twenty feet. We also learned that on November $18^{\text {th }}$ there had been strong shocks of earthquake at Philadelphia and in New York, as well as in other places on the coasts of northern America, but that they had caused no notable damage. This is the only allusion we know of, to a November $18^{\text {th }}$ tsunami on the coasts of New England : None of the British journals we consulted refers to anything of the kind, though their correspondents should have been on the front line to observe it. Furthermore, no French journal was in a 
position to obtain first-hand information about the coasts of North America, as there was a war between the two colonial empires, in which the French would lose their NorthAmerican possessions. The notion of twenty feet high waves tsunami hitting Boston is nothing but a figment of the imagination of a loose pen-pusher.

Professor Winthrop (Winthrop, 1757), even as he ascribes the tsunami in St Martin's to the Cape Ann earthquake, only acknowledges that the ships in the harbours were shaken and that some fish were floated belly up. Some other accounts of this earthquake (Philos. Trans., 1756e ; Colden, 1756 ; Philos. Trans., 1756f), published by the Royal Society earlier than Winthrop's, do not mention any sea-shore damages. Thus in Saint-Martin, as well as in all the other Caribbean islands, all accounts pertains to the tsunami caused by the Great Lisbon Earthquake : a conclusion which R. Rothman (Rothman, 1968) reached years ago.

\section{Conclusions}

\subsection{Methodology}

This critical review of the earliest accounts available on the tsunami of November 1st, 1755, on both sides of the Atlantic basin, allows us to reach beyond what each of these descriptions conveys. At each scale, local, regional or global, the analysis must not be just a juxtaposition of observations brought by all the various accounts. But the descriptions are not always complete : we often have to borrow one parameter from one document, another from a second one, and so on.

When the data reconstructed from several sources remains consistent, there is a good chance that these different sources actually originate from one single initial report, but that, in their effort to make the article they were editing appear as original, the second-hand compilers did not quite understand the fundamental unity of the phenomena they were summarizing. It should not be a surprise to find common descriptions in papers attributed to a single author (Ulloa 1756a \& b) but part of the data set were corrupt before they arrived to one of the journals. Finding that the letter of L. Godin to the French King and registered by the Académie Royale des Sciences de Paris (Godin, 1755) had a common origin with the letters by Ulloa was only possible through the comparison of the data reported in the account, and the same comparison again led us to observe that the Anonyme de Göttingen (1756/1772 ?) also had the same origin. The frame of these reports is also the same, however different the length of the various parts in each of them. On an identical basis of similarity of data and phrasing, the origins of the two reports on this tsunami published in the middle of the $19^{\text {th }}$ century in Martinique (Daney, 1846 ; Rufz, 1850), appear to be the same.

In most cases, the tsunami was correctly evaluated by the original describers, as long as they only described events which they actually witnessed, or at least only transcribed descriptions from true witnesses, in places which they personally knew. Trouble began when the authors tried to widen the scope of their account, gathering exogenous pieces of information.

When we have to face contradiction instead of redundant information, the discrepancies between the estimated parameters cannot be solved in any way other than blunt choice. The principles to solve such cases is to confront them with simple physiographic data : simple, because $18^{\text {th }}$ century geographic documents are generally not accurate enough to allow any better, and some change in the layout may have taken place since the event; and then to judge which of the contradictory statements is to be trusted, according to the laws of Physics and to common sense, which should concur in this.

An example is the height of run-up in La Trinité, in Martinique : 3 feet $(0.975 \mathrm{~m})$ according to Lettée (1756) as against 30 feet $(9.75 \mathrm{~m})$ according to a letter read by Duhamel on March 
$24^{\text {th }}$ (Anonyme lu par Duhamel, 1756). This is an easy case : no one would have survived a $9.75 \mathrm{~m}$ wave to regret the wasted coffee. The discrepancy must result from the carelessness of a copyist, who wrote 30 (numerals) rather than 3 : or, under the impression of other extraordinary estimates already published for other places, he believed he was rectifying a mistake!

\subsection{Results}

Admittedly, Lisbon remains the populated place hardest hit both by the earthquake and by the tsunami. A new-built quay on which people had taken refuge against the fall of debris, was said to have been swallowed by the sea, to a depth of more than 100 fathoms (Lyell 1830). Reid (Reid, 1914) pointed out that the harbour of Lisbon was situated on the Tagus estuary, which was nowhere deeper than 5 fathoms : so that the masonry of the quay could only have been shattered and scattered on the bed of the Tagus' mouth. This is one of the few destruction of stonework attributed to the tsunami alone, apart from some length of the parapet of the Town walls of Cadiz : The alleged destructions of two fortresses in Ferragudo and Portimão (Tedim Pedrosa \& Gonçalves 2008) are spurious : the forts are still standing, if no longer in use.

On the Spanish coasts of the gulf of Cadiz, the quality of the reports is due to the presence of some outstanding individuals :

Louis Godin, a former member of the Académie Royale des Sciences de Paris, had been the originator and head of the geodetic expedition to Peru, in charge of measuring the length of one angular degree of the meridian arc, at the equator. He was the head of the Real Academia de Guardias Marinas (School of Naval Cadets) in Cadiz, in charge of the scientific courses of junior officers.

Antonio de Ulloa, an Officer in the Spanish Navy, had also been a member of the expedition to Peru, together with Jorge Juan y Santacilia : both had been rewarded with membership of several European Academies and Scientific Societies.

In 1755-56, besides his official reports to the Spanish authorities, the observations of Godin, intertwined with those of Ulloa, were circulated to the learned societies of Europe : Académie Royale des Sciences de Paris (both a letter from Godin and one from Ulloa, the anonymous text in French now in the Göttingen Georgia Augusta Library); Kongliga Svenska Vetenskaps Academiens.

Unfortunately, editorial conditions worked in such a way that these accounts were quickly forgotten : [1] the Royal Society of London did not receive a proper copy of Ulloa's letter, but they published under his name an adulterated abstract obtained from the Netherlands : due to the high status of the Philosophical Transactions, the best known published account now conveys the enormous tall-story of 60 feet high waves in Cadiz; [2] a bad choice by the French Royal Academy of Paris was to reserve the subject of Earthquakes and Tsunami until $\mathrm{Ph}$. Buache, the King's Geographer and a member of the Academy, would be ready to deliver a synthesis on the subject : he died sixteen years later, leaving only a series of illassorted reports received at the Academy, at best registered, but never circulated: the French Royal Academy of Paris did not publish anything of value, despite the fact that they had received the two best reports on the subject. How their un-recorded letter from Ulloa came to be published as the brochure now found in the Georgia Augusta Library in Göttingen is not clear : it was printed any time between 1756 and 1772, and it is strange that it does not bear any editorial indication or bookshop where to obtain it. Its distribution being limited, it 
made no strong impression at the time, and was ignored by later generations. The official Spanish report, still extant (Martínez Solares \& López Arroyo, 2004), remained confidential. The quality of the reports deriving from observations by Godin and Ulloa is such that they must be established as the yardstick by which measure the other accounts and the likelihood of the physical parameters implied by or deduced from the descriptions, after the necessary critical examination of the physical setting of the events described. These reports provide a moderate figure for the amplitude of the tsunami : $2.51 \mathrm{~m}$.

When this earthquake occurred, the fact that tsunami result from earthquakes was only understood in areas where both are frequent, if not always catastrophic (Windward Islands). "If the ground had shaken, it would be said that it was the reason" (Lettee (1756). The notion that tsunami could strike totally unaware areas, across a whole oceanic basin, was not understood at all. The confusion of Winthrop was due to this un-established notion of travel beyond the distance of earthquake perception.

The result of the study is that the best known testimonies, constantly referred to by the scientific community for $2 \& 1 / 2$ centuries, are the most striking ones, those which describe the worse apocalyptic waves... if a superlative can apply to the Apocalypse. The point is that, except in Lisbon and in Cadiz, reliable descriptions of structural damages to the harbours and towns stricken, are generally lacking. More reasonable witnesses reported moderate measurements or estimates, almost everywhere: but when they attempted to extend their words beyond what they had actually seen by themselves, most overindulged in sensationalism. The amplitude at shoreline of the November $1^{\text {st }}$ tsunami may have been $5 \mathrm{~m}$ in Lisbon, but it decreased to $2.5 \mathrm{~m}$ in the Gulf of Cadiz and in northern Morocco, to less than $2 \mathrm{~m}$ in Galicia and in southern Morocco. It must have been about $1 \mathrm{~m}$ in the Atlantic islands (Madeira) and decreased further to $0.7 \mathrm{~m}$ in the Caribbean Islands.

Can such result be favourable to the safety of people, coastal establishments and activities ?

It can give us confidence in the modelling experiments conducted to estimate the local risks : it has now been a long time since M.A. Baptista concluded that the mathematical models could not simulate wave higher than $10 \mathrm{~m}$, in the Ibero-Moroccan Gulf, when investigating plausible seismic sources (Baptista et al., 1998).

Does it mean that moderate estimates of the tsunami amplitude decrease the risks? The mechanical parameters were sometimes widely exaggerated, but the sufferings of the coastal population were quite real. Risks which were believed attached to tsunami amplitudes of 10 to $15 \mathrm{~m}$ are in fact attached to amplitudes at shore between 2 and $3 \mathrm{~m}$.

The need for efficient warning systems can only be made more urgent by such a conclusion.

\section{Acknowledgements}

The author gratefully acknowledges the contribution of Frau Cornelia Pfordt, Librarian in the Niedersächsische Staats- und Universitätsbibliothek Göttingen, in tracing the origin of the brochure referenced here as the Anonyme de Göttingen. The author's thanks also go to Madame Rose-Marie Benoistel-Roebook for the translation from Dutch to French of the texts extracted from the Leidse Courant (1756). Thanks are also due to Dr Ana Maria Baptista for informally reviewing an early version of this chapter.

\section{References}

(Most Anonymous reports are referenced by the name of the journal which published them or the Institution which detains the books recording them.) 
Abeille Mrr 1756. Relation de ce qui s'est passé en Bretagne pendant le cours du mois de novembre 1755 au sujet des secousses de tremblement de Terre. P. V. Séances Acad. Sci. Paris, 75, 1-3, 7 janvier 1756.

Affleck Capt., 1756. CIII. An Account of the Agitation of the Sea at Antigua, Nov. 1, 1755. Philos. Trans. Roy. Soc. XLIX (II) 668-670.

Anonyme "de Göttingen", 1756/1772. Relation du tremblement de terre arrivé à Cadix le premier de novembre 1755. Booklet, $16 \mathrm{pp}$.

Anonyme "lu par Duhamel", 1756. Extrait... d'une lettre de la Martinique, du 15 Décembre dernier. P. V. Séances Acad. Sci. Paris, 75, 145, 24 mars 1756.

Ballet J., 1896, La Guadeloupe: Renseignements sur l'Histoire, la Flore, la Faune, la Géologie, la Minéralogie, l'Agriculture, le Commerce, l'Industrie, la Législation, L'administration. Imprimerie du Gouvernement, Basse-Terre. T. 2, pp. 286-287.

Baptista M.A. \& J.M. Miranda, 2009. Revision of the Portuguese catalog of Tsunamis. Nat. Hazards Earth Syst. Sci. 9, 25-42.

Baptista M.A., P.M.A. Miranda, J.M. Miranda, \& L. Mendes Victor, 1998. Constraints on the source of the 1755 Lisbon tsunami inferred from numerical modelling of historical data on the source of the 1755 Lisbon tsunami. J. Geodynamics, 25 (2) 159-174.

Bewick B., 1756. LIX. LETTER XIV. An account of the Earthquake at Cadiz, Novem. 1, 1755. Philos. Trans. Roy. Soc. XLIX (I) 424-427.

Blanc P. -L., 2008. The tsunami in Cadiz on 1 November 1755: a critical analysis of reports by Antonio de Ulloa and by Louis Godin, C.R. Geoscience, 340 (4), 251-261.

Blanc P. -L., 2009. Earthquakes and tsunami in November 1755 in Morocco: a different reading of contemporaneous documentary sources, Nat. Hazards Earth Syst. Sci., 9, 725-738.

Blanco-Moyano B., 2005. 250 Aniversario del Tsunami que Barrió Andalucía Occidental. Marina Civil, (79) 59-64 (Oct.-Dec. 2005). (Excerpts of L. Godin, A de Azlor and B. Ramos da Vila).

Borlase W., 1756. LVIII. LETTER XV. In Cornwall : At Mount-Bay \& Penzance. Philos. Trans. Roy. Soc. XLIX (I) 373-378.

Castro, D. A. L. F. : Historia Geral de Portugal e suas conquistas, Database Fundo Antigo, Academia de Ciências de Lisboa, Livro 1, Capitulo IV, Manuscript 691, 21-36, 1786 (in Portuguese ; fide Baptista \& Miranda 2009).

Chambers Ch., 1756. LIX. LETTER XVIII. Another account of the same Earthquake at Madeira, Novem. 1, 1755. Philos. Trans. Roy. Soc. XLIX (I) 435-436.

Colden C., 1756. LIX. LETTER XXI[B] An account of the Earthquake felt in New York, Novem. 18, 1755. Philos. Trans. Roy. Soc. XLIX (I) 443.

Cottrel Ph. 2003. Journal d'un vieil habitant de Sainte-Marie (1745-1765). Malesherbes.

Daney S., 1846. Histoire de la Martinique depuis la colonisation jusqu'en 1815. Fort-Royal, E. Ruelle, Imprimeur du Gouvernement. 1846. T. III, pp. 237-238.

Dawson A.G., R.M.W. Musson, I.D.L. Foster \& D. Brunsden 2000. Abnormal historic seasurface fluctuations, SW England. Marine Geology 170, 59-68.

Desvarennes $\mathrm{Mr}$, 1755. Nouvelles de Cadix. Du 4 noveme 1755. Archives Nationales, Fond Marine B7/396. 3 p. Annexée à Partyet, 1755

Fowke Th., 1756. LIX. LETTER XVI. An account of the Earthquake, that happened in Barbary. Philos. Trans. Roy. Soc. XLIX (I) 428-432.

Frishman Abbé de, 1755. Relation d'un tremblement de terre arrivé à La Corogne capitale de la Galice et dans les environs. Lettre de M. l'Abbé de Frishman du 79 bre 1755. Archives Nationales de France, Fond Affaires Etrangères, B1/255. 
Gardi A., A. Silva, M. Koscielny, E. Alparslan, R. Guillande, B. Ranguelov, N. Valencia, A. Atillah, S. Scheer, St. Tinti \& Ph. Buckle, 2009. Scenarios for Hazard-induced Emergencies Management: State of the art. GSC report D1.1, 90 pp. , February, 16 2009 (Excerpt of : Annotations made by the Priest of Saint Julian Church).

Gazette d'Amsterdam (Anonyme) 1756. Gaz. Amsterdam, VII, 23 Janvier 1756.

Gent's Mag., 1755 (Anonymous). Gentleman's Magazine, XXV, p. 521, November 1755.

Gent's Mag., 1756a (Anonymous). Gentleman's Magazine, XXV, p. 563-564, December 1755

Gent's Mag., 1756b (Anonymous). Gentleman's Magazine, XXV, Supplement, p. 589-591

Godin L., 1755. Sur le Tremblement de Terre qui s'est fait sentir à Cadix le 1er novembre 1755 (lu par Bouguer). P. - V. Acad. Roy. Sci. Paris, 74, 772-781, 3 \& 6 décembre 1755.

Heberden Th., 1756. LIX. LETTER XVII. An account of the Earthquake in the Island of Madeira, Nov. 1, 1755. Philos. Trans. Roy. Soc. XLIX (I) 432-434.

Hen. Tom., 1756. LVIII. LETTER XXIV. At Cork. Philos. Trans. Roy. Soc. XLIX (I) 393-394.

Holdsworth Revd, 1756. XCVII. At Dartmouth, relating to the Agitation of the Waters observed there on the $1^{\text {st }}$ of November, 1755. Philos. Trans. Roy. Soc. XLIX (II) 643644.

Hillary W., 1756. Observations on the Changes of the Air and the Concomitant epidemical Diseases in the Island of Barbadoes. London, 1756.

Huxham J., 1756. LVIII. LETTER XIV. In Devonshire and Cornwall; At Plymouth, MountBay, Penzance \& c. Philos. Trans. Roy. Soc. XLIX (I) 371-373.

JHMT, 1755 (Anonyme). Jour. Hist. Mat. tems. LXXVIII, p. 473-474. , Déc. 1755

JHMT, 1756a (Anonyme). D'Espagne. Jour. Hist. Mat. tems. LXXIX, p. 42-46. janv. 1756.

JHMT, 1756b (Anonyme). D'Espagne... Afrique... Amérique. Jour. Hist. Mat. tems. LXXIX, p. 131-139, fév. 1756.

JHMT, 1756c (Anonyme), 1756. Iles Barbades. Jour. Hist. Mat. tems, LXXIX, p. 463-464, Juin 1756.

Kaabouben F., M. A. Baptista, A. Iben Brahim, A. Toto \&, A. El Mouraouah, 2009. On the Moroccan Tsunami Catalogue. Nat. Hazards Earth Syst. Sci., 9, 1227-1236.

Leidse Courant, 1756a (Anonymous). Leidse Vrydagse Courant, n 4, 9 January 1756.

Leidse Courant, 1756b (Anonymous). Leidse Vrydagse Courant, ${ }^{\circ}$ 9, January 1756, fide J. Vogt. Lettée $\mathrm{M}^{\mathrm{r}}$, 1756. Extrait d'une lettre écrite par M Lettée dattée de la Martinique du Fort St.Pierre le 5 novembre 1755. P. V. Séances Acad. Sci. Paris, 75, 48-49, 28 janvier 1756.

Lima V.V., J. M. Miranda, M. A. Baptista, J. Cataláo, M. Gonzalez, L. Otero, M. Olabarrieta, J. A. Álvarez-Gómez \& E. Carreño, 2010. Impact of a 1755-like tsunami in Huelva, Spain. Nat. Hazards Earth Syst. Sci., 10, 139-148.

Lond. Chron., 1761 A (Anonymous). Extract of a letter from Cork, March 31. Lond. Chron. IX (670), p. 350.

Lond. Chron., 1761 B (Anonymous). A letter from Kinsale... Lond. Chron. IX (671), p. 358.

Lond. Gaz., 1755 (Anonymous). Madrid, Nov. 10. London Gazette n 9532. Nov. 25-29, 1755.

Lyell Ch., 1830. Principles of Geology. John Murray, Albemarle-Street, vol 1, 511 p.

Martínez Solares J.M. \& A. López Arroyo., 2004. The great historical 1755 earthquake. Effects and damage in Spain. Journal of Seismology. 8 (2), 275-294.

Mendes-Victor L., A. Ribeiro, L. Matias, M.A. Baptista, J.M. Miranda, P. Miranda, N. Zitellini, E. Garcia, C. Corela, P. Terrinha, M. Rovere \& F. Teixeira, 2005. Progresses in the Assessment of Tsunami Genesis and Impacts around the Portuguese Coasts, 217-230 in Tsunamis, Case Studies and Recent Developments, Adv. Nat. and Technol. Hazards Res., Vol. 23, Satake, K. (Ed.), 2005, VIII, 356 p.

Mercure de France, 1755 (Anonymous). Nouvelles étrangères. De Madrid, le 10 Novembre. Merc. France, Vol. I, p. 241-244 
Muysson Mons., 1756. LIX. LETTER XII. Concerning the Earthquake at Oporto, Nov. 1, 1755. Philos. Trans. Roy. Soc. XLIX (I) 422-423.

Nicola L., 1756. LVIII. Letter XXIII. At Kingsale. Philos. Trans. Roy. Soc. XLIX (I) 391-393.

Partyet Mr, 1755a. Lettre consulaire de Madrid du 10 Novembre 1755. Archives Nationales de France/ Marine B7/396.

Partyet $\mathrm{M}$ r $1755 b$. Extrait de plusieurs lettres que le Général de St François a reçues des Missionnaires de son ordre qui se trouvent Dans le Royaume de Maroc. Annexe à la lettre consulaire de Madrid du 22 décembre 1755. Archives Nationales de France/ Marine B7/396.

Pérez-Gómez B., 2009. Tsunamis. Puertos informa 154, 5-19. (excerpts from L. Godin and Ch. Lemaur)

Philos. Trans., 1756a (Anonymous). Philos. Trans. Roy. Soc., LVIII. Extract of LETTER XVI from Swansey. Vol. XLIX (I) 379-379.

Philos. Trans., 1756b (Anonymous). Philos. Trans. Roy. Soc., LIX. Extract of LETTER VIII concerning the earthquake at Oporto in Portugal, Nov. 1, 1756. Vol. XLIX (I) 418419

Philos. Trans., 1756c (Anonymous). LIX. Extract of LETTER X from Oporto, dated Novem. 1, 1756. Philos. Trans. Roy. Soc., Vol. XLIX (I) 421

Philos. Trans., 1756d (Anonymous). Extract of LETTER XI From Oporto, dated Novem. 1, 1756. Philos. Trans. Roy. Soc., LIX. Vol. XLIX (I) 421-422

Philos. Trans., 1756e (Anonymous). LIX. LETTER XXI[A] An account of the Earthquake felt at Boston in New-England, Novem.18, 1755. Philos. Trans. Roy. Soc., Vol. XLIX (I) 439-442.

Philos. Trans., 1756f (Anonymous). LIX. LETTER XXII An account of the Earthquake felt at Boston in New-England, Novem. 18, 1755. Philos. Trans. Roy. Soc., Vol. XLIX (I) 444.

Reid H.F., 1914. The Lisbon Earthquake of November 1, 1755. Bull. Seismological Soc. America, IV (2), 54-80.

Roger. J., S. Allgeyer, H. Hébert, M.A. Baptista, A. Loevenbruck \& F. Schindelé, 2010. The 1755 Lisbon Tsunami in Guadeloupe Archipelago: Source Sensitivity and Investigation of Resonance Effects. Open Oceanogr. Journ., 4, Special Issue 1. 58-70.

Rothman, R. L. 1968. A Note on the New England Earthquake of November 18, 1755. Bull. Seismological Soc. America, 50 (5), 1501-1502.

Rufz de Lavison É., 1850. Études historiques et statistiques sur la population de la Martinique. à Saint-Pierre. T. 1, p. 394.

Tedim Pedrosa F. \& J. Gonçalves 2008. The 1755 earthquake in the Algarve (South of Portugal) : what would happen nowadays? Adv. in Geosci., 14, 59-63.

Ulloa A. de, 1756a. LIX. LETTER XV. An account of the Earthquake at Cadiz. Philos. Trans. Roy. Soc. XLIX (I) 427-428.

Ulloa A. de, 1756b. Utdrag as en berättelse, om Jordbäsningen, som kändes i Cadix, den 1 :sta November År 1755. Kongl. Svensk. Vetensk. Acad. Handlingar, 17, 139-145.

Winthrop Prof., 1757. An Account of the Earthquake felt in New England, and the neighbouring Parts of America, on the $18^{\text {th }}$ of November, 1755. Philos. Trans. Roy. Soc., L (I) 1-18.

Wolsall Mr. 1756. LIX. LETTER II. An Account of the Earthquake at Lisbon, Nov. 1. 1755. Philos. Trans. Roy. Soc. XLIX (I) 402-407. 


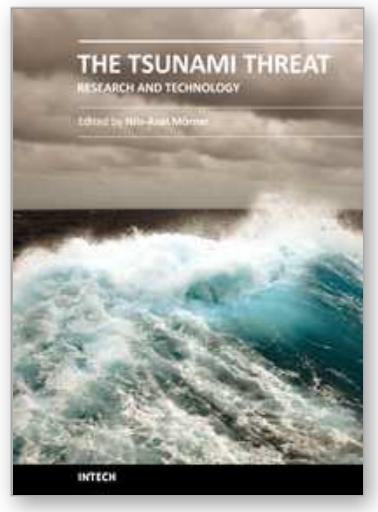

\author{
The Tsunami Threat - Research and Technology \\ Edited by Nils-Axel MÃ
}

ISBN 978-953-307-552-5

Hard cover, 714 pages

Publisher InTech

Published online 29, January, 2011

Published in print edition January, 2011

Submarine earthquakes, submarine slides and impacts may set large water volumes in motion characterized by very long wavelengths and a very high speed of lateral displacement, when reaching shallower water the wave breaks in over land - often with disastrous effects. This natural phenomenon is known as a tsunami event. By December 26, 2004, an event in the Indian Ocean, this word suddenly became known to the public. The effects were indeed disastrous and 227,898 people were killed. Tsunami events are a natural part of the Earth's geophysical system. There have been numerous events in the past and they will continue to be a threat to humanity; even more so today, when the coastal zone is occupied by so much more human activity and many more people. Therefore, tsunamis pose a very serious threat to humanity. The only way for us to face this threat is by increased knowledge so that we can meet future events by efficient warning systems and aid organizations. This book offers extensive and new information on tsunamis; their origin, history, effects, monitoring, hazards assessment and proposed handling with respect to precaution. Only through knowledge do we know how to behave in a wise manner. This book should be a well of tsunami knowledge for a long time, we hope.

\title{
How to reference
}

In order to correctly reference this scholarly work, feel free to copy and paste the following:

Paul-Louis Blanc (2011). The Atlantic Tsunami on November 1st, 1755: World Range and Amplitude According to Primary Documentary Sources, The Tsunami Threat - Research and Technology, Nils-Axel MÃ rrner (Ed.), ISBN: 978-953-307-552-5, InTech, Available from: http://www.intechopen.com/books/the-tsunami-threatresearch-and-technology/the-atlantic-tsunami-on-november-1st-1755-world-range-and-amplitude-accordingto-primary-documentary

\section{INTECH}

open science | open minds

\author{
InTech Europe \\ University Campus STeP Ri \\ Slavka Krautzeka 83/A \\ 51000 Rijeka, Croatia \\ Phone: +385 (51) 770447 \\ Fax: +385 (51) 686166 \\ www.intechopen.com
}

\author{
InTech China \\ Unit 405, Office Block, Hotel Equatorial Shanghai \\ No.65, Yan An Road (West), Shanghai, 200040, China \\ 中国上海市延安西路65号上海国际贵都大饭店办公楼 405 单元 \\ Phone: +86-21-62489820 \\ Fax: +86-21-62489821
}


(C) 2011 The Author(s). Licensee IntechOpen. This chapter is distributed under the terms of the Creative Commons Attribution-NonCommercialShareAlike-3.0 License, which permits use, distribution and reproduction for non-commercial purposes, provided the original is properly cited and derivative works building on this content are distributed under the same license. 